\title{
Traditional Knowledge of Homegarden-Dry Field Agroforestry as a Tool for Revitalization Management of Smallholder Land Use in Kulon Progo, Java, Indonesia
}

\author{
Priyono Suryanto (Corresponding author) \\ Faculty of Forestry, Universitas Gadjah Mada, Yogyakarta, Indonesia \\ Tel: 62-274-550-542Ｅ-mail: psuryanto@ugm.ac.id \\ Siti Muslimah Widyastuti \\ Faculty of Forestry, Universitas Gadjah Mada, Yogyakarta, Indonesia \\ Junun Sartohadi \\ Faculty of Geography, Universitas Gadjah Mada, Yogyakarta, Indonesia \\ San Afri Awang \\ Faculty of Forestry, Universitas Gadjah Mada, Yogyakarta, Indonesia
}

Budi

Postgradute Student, Faculty of Forestry, Universitas Gadjah Mada, Yogyakarta, Indonesia

Received: December 5, 2011

Accepted: December 21, $2011 \quad$ Published: April 1, 2012

doi:10.5539/ijb.v4n2p173

URL: http://dx.doi.org/10.5539/ijb.v4n2p173

\begin{abstract}
Agroforestry homegarden-dry field are the last biodiversity resort of land management which synergizes the production and the conservation as well. Market orientation changes will encourage dry field homegarden monoculturization to be a threat. Based on these considerations homegarden-dry field has a degree of urgency for management revitalization to do. This study aims to determine the traditional knowledge of homegarden-dry field agroforestry management and its developer's revitalization scheme. This research was conducted in Kulonprogo Regency, Java, Indonesia with three agroecological zones of the Kulon Progo Coastal Plain (cluster 1); Kulon Progo Plain (cluster 2) and Kulon Progo Hills-Mountains zone (cluster 3).

The traditional practices that are developed in the agroforestry management can be seen from the space arrangement in the homegarden-dry fields that seems to be perfunctory. On its function connectivity there is an overlap among the cultivated species -trees and seasonal crops- but its productivity is low. However, crop and tree species diversity in agroforestry systems is higher compared to agriculture and forest crops. Based on these considerations then revitalization management of agroforestry homegarden-dry field (RMA-HD) is made by integrating in a single management unit. Through RMA-HD schemes, agroforestry in the outside part of the forest will have a new management approach, and may be promising for agroforestry reference in Indonesia, particularly for the pro-poor program which is compatible with the intensive smallholder management.
\end{abstract}

Keywords: Traditional knowledge, Agroforestry, Revitalization, Homegarden, Dry field

\section{Introduction}

The strength of forest rehabilitation in Indonesia has not been able to halt deforestation. Rehabilitation targets which are set by the government as wide as of 18.7 million ha area from 1970 until 2004 has not been achieved. Degraded forest area which should be 24.9 million ha, yet now is increased to 42.6 million ha. Thus the long history of rehabilitation is in the status "has not been successful" (Nawir and Rumboko, 2007). Whereas in some 
countries such as Bhutan, India and Vietnam during 2000-2005 there was an increase of its forest closures and even in China has rehabilitation pace of 4 million ha per year (FAO, 2007).

On the other hand farming systems continues to develop with high external inputs (Reintjes and Bayer, 1992). Management of natural resources had serious problems with global warming. This impact is more evident with its continued crops failure. Food crisis, energy, biodiversity and the overall environment become major problems in the management of natural resources in Indonesia. However, the cultivation of trees outside the forest continues to grow and its existence has increasing role as a support in the production function as well as the ecosystems (FAO, 2006). Biodiversity has an important role in maintaining ecosystem resilience in facing natural resources damage (environmental shocks) which continues to increase. Besides rehabilitation with agroforestry techniques (homegarden-dry field) is able to enhance biodiversity conservation (Schroth et al., 2004).

In Indonesia these trees are developed in homegarden-dry field management which later became an important reference in land management that meets the principles of sustainability (sustainable epitome). Homegarden-dry field management looks very simple, traditional, seems to be conventional and even its research or development program are almost forgotten by the parties. However behind it all, the homegarden-dry field becomes farmers' safety net as well as, overall, ecosystem savior among other land management, primarily with monoculture based.

Homegarden-dry field is the last biodiversity resort of land management which synergizes the production and conservation as well. Biodiversity safety in the future will depend on the homegarden-dry field management. Market orientation changes will encourage homegarden-dry field monoculture to become a threat (trade off). In one hand it promotes productivity, yet on the other hand it declines biodiversity. This would be a serious problem especially nowadays the rice field as food barns have undergone chaos due to prolonged crop failures.

Homegarden as part of agroforestry systems in its development has experienced a serious threat because of the urbanization and land use change and the changes in its constituent components which are more likely to monocultures (Kumar and Nair, 2004; Suryanto et al., 2011a). The mandate of the homegarden-dry field based agroforestry that continues to develop from the timber to this ecosystem is increasingly apparent with the existence of global warming is a serious problem. Agroforestry plays an important role in mitigating climate change-carbon absorption capacity-which recently gets serious attention of the parties (IPCC, 2000; 2007).

Homegarden-dry field commercialization becomes a reality in response to the narrowing of land area and climate change, but preparing the management which retains the typical pattern which has become the trademark of the homegarden-dry field (as the epitome sustainable) also becomes a necessity. The demands of homegarden-dry field management to produce more commodities as well as high biodiversity will be an adaptation step towards the climate change. Based on these considerations then homegarden-dry field has a degree of urgency for revitalization management to do. This study aims to determine the traditional knowledge of homegarden-dry field agroforestry management and its developer's revitalization scheme.

\section{Methods}

This research was conducted in Kulonprogo Regency, Yogyakarta Province with the basic considerations of the representative practices developed in Java and can be used as a management miniature in Indonesia over the homegarden-dry field. This research was conducted in three agroecological zones in the Kulonprogo Mountains zone district, Kulonprogo Hills (KH), Kulonprogo Plain (KP), and the Kulonprogo Coastal Plain (KC). Sample unit in this study are farmers who own homegarden-dry field in every identified pattern. In KH, KP and KC zones homegarden-dry field management will be sampled and based on cluster analysis. Identification of society's silvicultural and agronomic knowledge conducted with a sample survey of farmers (respondents).

The survey was conducted by in depth interviews about society's knowledge aspects of land process, planting techniques, plant maintenance, homegarden-dry field management and the factors that influence it. Based on the data, visualization is made about the typology of homegarden- dry fields agroforestry, determinant factors of species diversity in agroforestry systems, the trend of agroforestry dynamics based on land width, agroforestry management techniques, agroforestry classification based on its types designation and assessment towards its management implementation and homegarden-dry field agroforestry management revitalization scheme.

\section{Results}

Homegarden management in the District Kulonprogo based on the zoning system which can be classified into 3 namely low land homegarden (cluster 1), medium land (cluster 2) and up land (cluster 3). Homegarden in cluster 1 is characterized by conventional crop types that are selected and poorly managed, low diversity of its crop products, low input, low trees product, low resiliency and the tree planting is usually exist on a border that also functioned as 
a fence (Figure 1). Crop management in cluster 1 field is more intensive, with high external inputs, high productivity, low crop diversity, since it is market-based, medium resiliency, and cropping patterns used is by the surjan system (raised/sunken bed system).

Homegarden in cluster 2 and cluster 3 have a resemblance that is intensive in the use of space, crop and product diversity is high, with low external input, high wood products, high levels of resilience and the cropping systems with trees on the border. Dry field in the cluster 2 and 3 also has a resemblance that is intensive in the use of vertical and horizontal space, with high crop diversity, low external-input, low crop product, high timber productivity, high resiliency and cropping systems with alley cropping (Figure 1).

Diversity increase in the homegarden-dry field systems in cluster 1,2 and 3 is influenced by land width, market access and altitude. Diversity decrease is strongly influenced by the presence of the commercialization of products and total productive forces (Figure 2).

Tendency of species richness in the homegarden-dry field systems in cluster 1, 2 and 3 based on land width owned by farmers showed that the vaster land, the higher its level of species richness. It is the same for the species richness for seasonal crops. The division of space in the homegarden-dry field system in the area showed that in smaller width the number of cash crop is high, while the perennial food crops and the annual food crop are low. In the large field condition showed the opposite condition, that is an increase in the number of annual and perennial food crop while the cash is low (Figure 3).

The number of trees, volume and number of fast growing tree species showed the same trend that is the bigger the land width the higher the value. This trend is also similar for the supply of green fodder (Figure 3).

Traditional tress cultivation in homegarden-dry field system showed that seedlings originated from natural regeneration and some also use polybags in limited numbers (clusters 1, 2 and 3). Beside in cluster 2 and 3 also use the scraped, seeds, cuttings and shoots systems. In cluster 3 there also develops a system of graft. Planting techniques in general in cluster 1 is by using a design, especially for dry fields, because it is for seasonal plant with surjan system. While in cluster 2 and 3 are not based on a special scheme (Table 1).

Maintenance in the cluster 1 is more intensive compared to cluster 2 and 3 namely by doing tillage and fertilization. In addition the maintenance performed on all clusters is pruning and thinning. Harvesting system used is known by the term tebang butuh (based on the urgency of the farmers' needs harvesting). In general, cluster 1 management used is intensive while in cluster 2 and 3 tends to the conventional one. Constraints in homegarden management and dry field for cluster 1, i.e high external inputs and for cluster 2 and 3 that is typology footprint that has a high slope (Table 1).

Based on the types function cultivated in homegarden-dry field system, it shows that cluster 1 is more dominated by a few species only. While in cluster 2 and 3 type composition based on its function more varies. Cluster 1 is more focused on several types that have high commercial value while in cluster 2 and 3 the cultivated types is more various so it is very intensive in the use of space (Figure 4).

Homegarden-dry field management in all the clusters indicate that there is lack of function connectivity. It can be seen from the type arrangement used, overlapping between home-garden and dry fields exist. Low productivity in both the homegarden-dry field makes the income for the owners still low (subsistence). In an effort to improve productivity function as well as ecology homegarden-dry field development scenario will be required.

There are two steps that need to be prepared namely connectivity and capacity increase. Connectivity improvement is done through the function revitalization of homegarden-dry field. Homegarden needs to be focused on the production of farmers' routine needs (food and vegetable). While in dry field, which is commonly used for the production of food crops is arranged with a focus on food in the context of superior commodities (herbal) or synergized with livestock activities by the cultivation of forage grass and other forages.

Trees cultivation in the homegarden system is focused on multipurpose trees species so that the results obtained have a high diversity. Dry field is arranged with potential tree species especially the blend between fast growing with slow growing species. Homegarden-dry field revitalization is designed in both units as one unit so between the compatible management among both clusters is high. The connectivity in homegarden-dry field is not only on land unit based on its ownership but also based on a landscape level. In this scheme connectivity scheme needs to be built between landscape in cluster 1,2 and 3. Revitalization in this landscape level can be the foundation in building payment environmental services scheme.

Capacity increase is done through the skill for agroforestry technology namely skills in silviculture and agronomy. Silviculture is needed to support the trees productivity and agronomy to increase the productivity of seasonal crops. Beside capacity increase is also conducted in processing products for the wood, non wood and 
seasonal crops. This capacity is not only on farmers' level but also among the farmers by strengthening farmer groups. Thus sharing culture is built on the best practice in cluster 1, 2 and 3 .

The third step is the increase in partisanship to homegarden- dry field agroforestry based management based. In this context the agroforestry not only be owned by proprietor farmers, but also other stakeholders. This revitalization should receive full support especially from local government so that the existence of agroforestry is not surpassed by any other development interests.

In this revitalization enabling condition is needed, which includes technology support, research, and market, government commitment, good communications practice, policy support and reward support. With these enabling conditions, scaling up can be done to speed up the revitalization process with the impact on poverty reduction, resilience increase and ecological capacity as well. The culmination of this revitalization is the prospective and sustainable agroforestry (Figure 5).

\section{Discussion}

Agroforestry practice (homegarden-dry fields) in Indonesia is generally done traditionally known as an approach that is impressed as 'perfunctory'. It also includes the agroforestry which is developed in Kulonprogo, Java, which uses the traditional approach to ecological knowledge (TEK). Knowledge developed in the agroforestry management runs from generation to generation. TEK not only knowledge but also practices and beliefs that are more-or-less integrated with one another (Berkes, 1999). Traditional practices that are developed in the agroforestry management can be seen from the arrangement of space in the home-garden and dry fields of which its function connectivity is low.

Agroforestry practices that seemed perfunctory results in cultivated species of trees and crops overlapping, but with low productivity. The overlap with the low productivity becomes the marker that management carried out in the yard and the fields is not integrated in a single management unit although their owners are alike. These agroforestry practices are also developed in several locations; one of them is in the buffer zone on the southern slope of Mount Merapi National Park, Java (Suryanto et al., 2010). This agroforestry knowledge results the agroforestry management is still classified as subsistence. Agroforestry clusters which are based on the level of productivity are very dependent on peasant agroforests. Agroforestry pattern is considered as a functional pattern or related to the farmers' condition. Cluster agroforestry has been done based on structural, functional, socioeconomic, and ecological aspects (Nair, 1993; Ffolliott, 2003).

However, crop and trees species diversity in this agroforestry system is higher compared to agriculture and forest crops. It can be seen from the species based on its function namely for wood, food, medicinal, fruit, vegetables and other functions. Traditionally, homegarden is mainly characterized with the production of trees, fruits, shrubs, vegetables, medicinal plants and other crops to support staple food crops (Soemarwoto, 1987; Kumar and Nair, 2004). Agroforestry has a variety in species diversity compared to the traditional agricultural systems, although the level of species diversity is lower than the tropical forest. The rich diversity makes them ecologically resilient and thus gives them the ability to provide more and better ecological functions (Olson et al., 2000; Vandermeer, 2002).

The main factor that distinguishes agroforestry systems that developed in the District Kulonprogo is the land width. Farmers with big size of agroforestry will typically mix different types of plants that have a high level of diversity. Dominance of food crops in the use of space in agroforestry systems commonly found in small land area. Abebe (2005) argued that the pattern of agroforestry is very much influenced by size; this means if agroforestry involved big size, the trend in the species richness, as well as of trees and agricultural crops would also be high; although cash and perennial crops high were the resource persons but the annual crop was still low.

Traditionally agroforestry practices can also be seen from silvicultural practices that is developed namely the use of plant material. Seedlings originated from natural seedlings are more widely used with consideration of less expensive and easier. Although communities have also begun feeling the need to plant with the superior seeds for the type of Falcataria moluccana, coffee and some types of fruits like Durian, Nephelium lappaceum, and Parkia speciosa. According Roshetko and Manurung (2009) that the regeneration of $72 \%$ of farmers use wildings, seedlings of $30 \%$ local, $20 \%$ coppice, only $12 \%$ have used improved quality seedlings (Mainly through government reforestation programs) in the case study of Gunung Kidul Regency, Java. The composition of species that have a high density also show that silviculture technology has not been done intensively. Silvicultural techniques such as thinning for maintenance in agroforestry system which is also very low at $57 \%$, is not done (Roshetko and Manurung, 2009). No thinning for quality or to improve growth (reduce density). No thinning of coppice, traditional thinning equals harvesting the biggest thinning trees when families need money or popular with "tebang butuh" (harvest to meet needs). 
In prospective and sustainable agroforestry management efforts; then revitalization management agroforestry homegarden-dry field (RMA-HD) will be needed. There are three pillars in the agroforestry revitalization in Kulonprogo namely connectivity, capacity and ownership. The important connectivity in this revitalization scheme is the connectivity between homegarden-dry field as a single unit of management. Efforts to improve the connectivity of owned land with agroforestry scheme is also developed on the southern slope of Mount Merapi National Park (Suryanto et al., 2011a; Suryanto et al., 2011b) through the silviculture agroforestry regime approach. It is done to organize the potential types of trees and crop so it can avoid function overlapping which seems to be perfunctory.

Homegarden is more focused on daily necessities for owner farmers and dry field serves as a source of income, both its trees and crop. Agroforestry systems are created and intensively managed to maintain their productive and protective functions and interactions which often involve cultural operations such as cultivation, fertilization, pruning, and thinning (Gold et al., 2000). In order to maintain the positive characteristics of home-garden, therefore it is necessary to improve homegarden that counterbalances the on-going trend of homogenization (Kumar and Nair, 2004). This connectivity is more likely to lead to intensification of the homegarden-dry field. Agroforestry practices must be intentional, intensively managed and integrated, either horizontally or vertically, in order to manipulate interactions among the components (Gold et al., 2000).

Connectivity in this RMA-HD level is not based only on land but also in learning together. The success of a farmer and others needs to be strengthened as a medium of learning. One of the agroforestry approaches to accelerate agroforestry status which is learned by the farmer. The concept of farmer-to-farmer is popular as "Farm Link" (Shelton et al., 2009). Implementation of a farm link must be further facilitated to encourage integration of home-garden and dry fields based on the intensive agroforestry typology.

This RMA-HD must be supported by agroforest farmers' capacity increase through collective learning. The capacity for building support in instituting the link the between the farmers and establishing support mechanisms for capacity development is done as a collective learning. This capacity increase can be done through agroforestry research with collaboration between researchers with agroforest farmers. The directions in agroforestry research should (Nair, 1998) 'build bridges' from the past (examination), through the present (evaluation) and to the future (prognosis). The learning scheme is followed by synergy building between the agroforestry technological innovation and the silviculture regimes.

This revitalization needs the support not only from the homegarden-dry field landowner farmers but also other stakeholders. This clear evidence of agroforestry outside the forest that is developed in Kulonprogo, gives ecological value which can't be separated between the owner and not the owner. All community components get ecological value from this agroforestry management. Agroforestry de facto controls the poor farmers (Puri and Nair, 2004), thereby, the configuration agroforestry aids biodiversity conservation (Schroth et al., 2004).

It is therefore necessary to build a sense of belonging and importance of maintaining the existence of agroforestry in this home-garden and dry field. Strategies are aimed at some approaches to compatibles the goals concerning poverty, development and environment focus on the agricultural diversification and productive conservation (Perz, 2004). Moreover, conservation is not just for an ecosystem but it is also about managing people. In addition, a large part of the protected areas program is about empowering and assisting the people to manage themselves and the ecosystems (Barber, 2004a).

In a hierarchical approach, Sayer and Maginnis (2005) conclude that the ecosystem approach is replaced by the social learning concept of "we are learning together" whereas the sustainable forest management is slightly more open, which is based on the concept "we manage you participate". Meanwhile, as for sustaining the yields of forestry, Sayer and Maginnis (2005) mention that it is founded on the command and control concept of "we manage". Therefore capacity building for supporting revitalization of agroforestry homegarden-dry field are very important through learning together among the stakeholders. It is apart from increasing the skill level, also minimizes the mismatch and levels the playing of field-power sharing.

Additionally RMA-HD requires enabling condition namely local government support commitment, supportive policy, micro-finance scheme, communication in the agroforestry management, technical, research, and marketing support. Notably, RMA-HD is a compatible management that builds synergy between the intensive agroforestry management in the homegarden-dry field, which must be backed up by the legal policy. Having mentioned that, the policy can be improved through capacity building, legal counseling and government commitment. Supporting the poverty alleviation for forest-based communities requires a radical rethinking of forest policy (Larson and Ribot, 2007). On the other hand, compatibility depends on the power dynamics of the stakeholders represented in the policy maker (Spilsbury and Nasi, 2006). 
The scheme of RMA-HD also takes place within the same constraints as other 'development' activities (Colchester, 2004). This RMA-HD, as an integrative planning strategy, follows the implementation of monitoring and evaluating RMA-HD in participative way. In the integrative planning, it clearly states the long-term goals, objectives and continuous monitoring of the ecosystem (Brody, 2003).

However, a good enabling condition exists, whereby the effectiveness of the delivery or adaptation processes remains pivotal to successful innovation uptake and technology transfer (Spilsbury and Nasi, 2006). Policy makers set the framework and create an enabling condition that does not only support the protection of biological diversity, but adapts, as managers do, to the emerging threats and opportunities (Barber et al., 2004b). Enabling policies can facilitate the institutionalization of participatory approaches to implement RMA-HD.

In the development of RMA-HD in landscape perspective, a far more targeted approach is required to exploit the comparative advantage of different resource management strategies in order to minimize the one-size-fits-all strategy (Sayer, 2001; Sayer and Maginnis, 2005). Because every site is different, therefore, the management should be unique too. Hence, the framework for assessing the overall progress is useful, but it should be secondary to the need to truly attune the local realities in terms of the local needs, constraints and opportunities (Sayer, 2001).

\section{Conclusion}

In short, the implementation of RMA-HD requires a full support from stakeholders. Technology-and policy-based are two examples which represent the extremes in the delivery of agroforestry research (Sanchez, 1999). Without a sound technical documentation, the RMA-HD would not be as receptive as the suggested policy options. Similarly, without enabling policies, the breakthroughs in compatible management replenishment would not go far. Stakeholders, particularly local citizenry must be motivated to assume responsibility in a partnership (Aronson et al., 2006). Through RMA-HD scheme, agroforestry in the outside part of forest will have a new management approach and may be promising for agroforestry reference in Indonesia, particularly for the pro-poor program which is compatible with the intensive smallholder management.

\section{Acknowledgements}

We would like to express our gratitude to the farmers of Kulon Progo Regency, Java, Indonesia for their permission and assistance in conducting this research. The authors wish to thank postgraduate student at Faculty of Forestry, Universitas Gadjah mada (Indira, Dini and Budi). This research would have never been possible without the financial support from the Institute for Research and Community Services, Universitas Gadjah Mada (LPPM-UGM/757/BID.I/2011). Finally, we would also like to thank the two anonymous reviewers for their helpful comments and suggestions.

\section{References}

Abebe, T. (2005). Diversity in homegarden agroforestry systems in Southern Ethiopia, PhD Thesis, Wageningen University, Wageningen.

Aronson, J., Clewell, A. F., Blignaut, J. N., \& Milton. S. J. (2006). Ecological restoration: a new frontier for nature conservation and economics. Journal for Nature Conservation, 14, 135-139. http://dx.doi.org/10.1016/j.jnc.2006.05.005

Barber, C. V. (2004a). Parks and people in a world of changes: governance, participation and equity. In Securing Protected Areas in the Face of Global Change: Issues and Strategie, ed. C.V. Barber, K.R. Miller, and M. Boness, pp. 97-134. IUCN, Gland, Switzerland and Cambridge, UK.

Barber, C. V. (2004b). Designing protected area systems for a changing world. In Securing Protected Areas in the Face of Global Change: Issues and Strategies, ed. C.V. Barber, K.R. Miller, and M. Boness, pp. 41-96. IUCN, Gland, Switzerland and Cambridge, UK.

Berkes, F., Colding, J., \& Folke, C. (2000). Rediscovery of Traditional Ecological Knowledge as Adaptive $\begin{array}{llll}\text { Management. } & \text { Ecological } & \text { Applications, } & 10(5),\end{array}$ http://dx.doi.org/10.1890/1051-0761(2000)010\%5B1251:ROTEKA\%5D2.0.CO;2

Brody, S. D. (2003). Implementing the principles of ecosystem management through local land use planning. Population Environ, 24, 511-540. http://dx.doi.org/10.1023/A:1025078715216

Colchester, M. (2004). Conservation policy and indigenous peoples. Environmental Science \& Policy, 7,145-153. http://dx.doi.org/10.1016/j.envsci.2004.02.004 
Ffolliott, P. F. (2003). Agroforestry-A Primer. Tucson, AZ: School of Renewable Natural Resources, University of Arizona.

Food and Agricultural Organization (FAO). (2006). Global Forest Resources Assessment 2005-Progress Toward Sustainable Forest Management. FAO Rome, Italy.

Food and Agricultural Organization (FAO). (2007). State of the World's Forests. FAO Rome, Italy.

Gold, M. A., Rietveld, W. J., Garrett, H. E., \& Fisher, R. F. (2000). Agroforestry nomenclature, concepts, and practices for the USA. In North American Agroforestry: an Integrated Science and Practice, ed. H.E. Garrett, W.J. Rietveld, and R.F. Fisher, pp. 63-76. ASA, Madison,WI.

IPCC (Intergovernmental Panel on Climate Change). (2000). Land-use, Land-use Change and Forestry, ed. R. T. Watson, I. R. Noble, B. Bolin, N. H. Ravindranath, D. J. Verardo, and D. J. Dokken. Special report. Cambridge, Cambridge University Press.

IPCC (Intergovernmental Panel on Climate Change). (2007). Climate Change 2007; Mitigation, Contribution of Working Group III to the Fourth Assessment Report of the Intergovernmental Panel on Climate Change, ed. B. Metz, O. R. Davidson, P. R. Bosch, R. Dave, and L. A. Meyer. Cambridge University Press, Cambridge, USA, United Kingdom and New York, NY.

Kumar, B. M., \& Nair P. K. R. (2004). The enigma of tropical homegardens. Agroforestry Systems, 61, 135-152. http://dx.doi.org/10.1023/B:AGFO.0000028995.13227.ca

Larson, A. M., \& Ribot, J. C. (2007). The poverty of forestry policy: double standards on an uneven playing field. Sustainability Science, 2,189-204. http://dx.doi.org/10.1007/s11625-007-0030-0

Nair, P. K. R. (1993). An Introduction to Agroforestry. Dordrecht, the Netherlands: Kluwer Academic Publishers. http://dx.doi.org/10.1007/978-94-011-1608-4

Nair, P. K. R. (1998). Directions in tropical agroforestry research: past, present, and future. Agroforestry Systems, 38, 223-245. http://dx.doi.org/10.1023/A:1005943729654

Nawir, A. A., \& Rumboko, L. (2007). History and state of deforestation and land degradation. In Forest rehabilitation in Indonesia: where to after three decades? A.A. Nawir, Murniati, and L. Rumboko, pp. 11-32. Center for International Forestry Research (CIFOR). Bogor, Indonesia.

Olson, R. K., Schoeneberger, M. M., \& Aschmann, S. G. (2000). An ecological foundation for temperate agroforestry. In North American Agroforestry: An Integrated Science and Practice, ed. H.E. Garrett, W.J. Rietveld, and R.F. Fisher, pp. 31-61. Madison, WI: American Society of Agronomy.

Perz, S. G. (2004). Are Agricultural Production and Forest Conservation Compatible? Agricultural Diversity, Agricultural Incomes and Primary Forest Cover Among Small Farm Colonists in the Amazon. World Development, 32(6), 957-977. http://dx.doi.org/10.1016/j.worlddev.2003.10.012

Puri, S., \& Nair, P. (2004). Agroforestry research for development in India: 25 years of experiences of a national program. In New Vistas in Agroforestry: A Compendium for the 1st World Congress of Agroforestry, 2004, ed. P. Nair, M. Rao, and L. Buck. Advances in Agroforestry series, vol 1, Springer, New York, US.

Reinjntjes, C., Haverkort, B., \& Bayer, A. W. (1992). Farming for the future: an introduction to low-external-input and sustainable agriculture. MacMillan and ILEIA. Leusden, Netherlands.

Roshetko, J. M., \& Manurung,G. E. S. (2009). Smallholder Teak Production Systems in Gunung Kidul, Indonesia. The 2 World Congress of Agroforestry. Nairobi, 24-28..

Sanchez, P. A. (1999). Delivering on the promise of agroforestry. Environment, Development and Sustainability, 1, 275-284. http://dx.doi.org/10.1023/A:1010083007121

Sayer, J. A., \& Maginnis, S. (2005). New challenges for forest management. In Forest in Lanscapes: Ecosystem approaches to sustainability, ed. J.A. Sayer, and S. Maginnis, pp. 1-16. Earthscan.

Sayer, J. A. (2001). Learning and Adaptation for Forest Conservation. In Biological Diversity: Balanding interest through adaptive collaborative management, ed. L.E. Buck, C.C. Geisler, J. Schelhas, and E. Wollenberg, pp. 69-80.CRC Press. http://dx.doi.org/10.1201/9781420042597.ch4

Schroth,G., da Fonseca, G. A. B., Harvey, C. A., Vasconcelos, H. L., Gascon, C., \& Izac, A. M. N. (2004). Introduction: The Role of Agroforestry in Biodiversity Conservation in Tropical Landscapes. In Agroforestry and Biodiversity Conservation in Tropical Landscapes, ed. G. Schroth, G.A.B. da Fonseca, C.A. Harvey, C.Gascon, H.L. Vasconcelos, and A.M.N. Izac, pp. 1-12. Island Press. 
Shelton, D. P., Wilke, R. A., \& Franti, T. G. (2009). Farmlink: promoting conservation buffers farmer-to-farmer. Agroforest Systems, 75, 83-89.

Soemarwoto, O. (1987). Homegardens: a traditional agroforestry system with a promising future. In Agroforestry, a Decade of Development, ed. Steppler H.A. and Nair P.K.R, pp. 157-172. ICRAF, Nairobi, Kenya.

Spilsbury, M. J., \& Nasi, R. (2006). The interface of policy research and the policy development process: challenges posed to the forestry community. Forest Policy and Economics, 8, 193-205. http://dx.doi.org/10.1016/j.forpol.2004.09.001

Suryanto, P., Zaki, M. H., Azmy, M., \& Azani, M. A. (2010). Agroforestry typology and its implications on surrounding South Region of Gunung Merapi National Park, Java, Indonesia. The Malaysian Forester, 73, 2, 229-238.

Suryanto, P., Zaki, M. H., Azmy, M., \& Azani, M. A. (2011a). Silviculture Agroforestry Regime: Compatible Management in Southern Gunung Merapi National Park, Java, Indonesia. International Journal of Biology, 3(2), 115-126. http://dx.doi.org/10.5539/ijb.v3n2p115

Suryanto, P., Zaki, M. H., Azmy, M., \& Azani, M. A. (2011b). Exploring the Potential of Silviculture Agroforestry Regime as a Compatible Management in Southern Gunung Merapi National Park, Java, Indonesia. Journal of Sustainable Development, 4(3), 81-93. http://dx.doi.org/10.5539/jsd.v4n3p81

Vandermeer, J. H. (2002). Tropical Agroecosystems. Boca Raton, FL: CRC Press. http://dx.doi.org/10.1201/9781420039887

Table 1. Homegarden-dry field agroforestry management

\begin{tabular}{|c|c|c|c|}
\hline Type of management & Cluster 1 & Cluster 2 & Cluster 3 \\
\hline \multirow[t]{5}{*}{ Planting Material } & \multicolumn{3}{|c|}{ natural } \\
\hline & & \multicolumn{2}{|c|}{ wildling } \\
\hline & & \multicolumn{2}{|c|}{ seedling } \\
\hline & & \multicolumn{2}{|c|}{ cutting } \\
\hline & & & air layer \\
\hline \multirow[t]{2}{*}{ Planting Design } & with design & & \\
\hline & & \multicolumn{2}{|c|}{ no design } \\
\hline \multirow[t]{5}{*}{ Maintenance } & tillage & & \\
\hline & fertilizer & & \\
\hline & \multicolumn{3}{|c|}{ pruning } \\
\hline & \multicolumn{3}{|c|}{ pest and disease protection } \\
\hline & \multicolumn{3}{|c|}{ thinning } \\
\hline Harvesting & \multicolumn{3}{|c|}{ tebang butuh } \\
\hline \multirow[t]{2}{*}{ Management } & intensive & & \\
\hline & & \multicolumn{2}{|c|}{ conventional } \\
\hline \multirow[t]{2}{*}{ Constraint } & high input & & \\
\hline & & \multicolumn{2}{|c|}{ typology site/elevation } \\
\hline
\end{tabular}




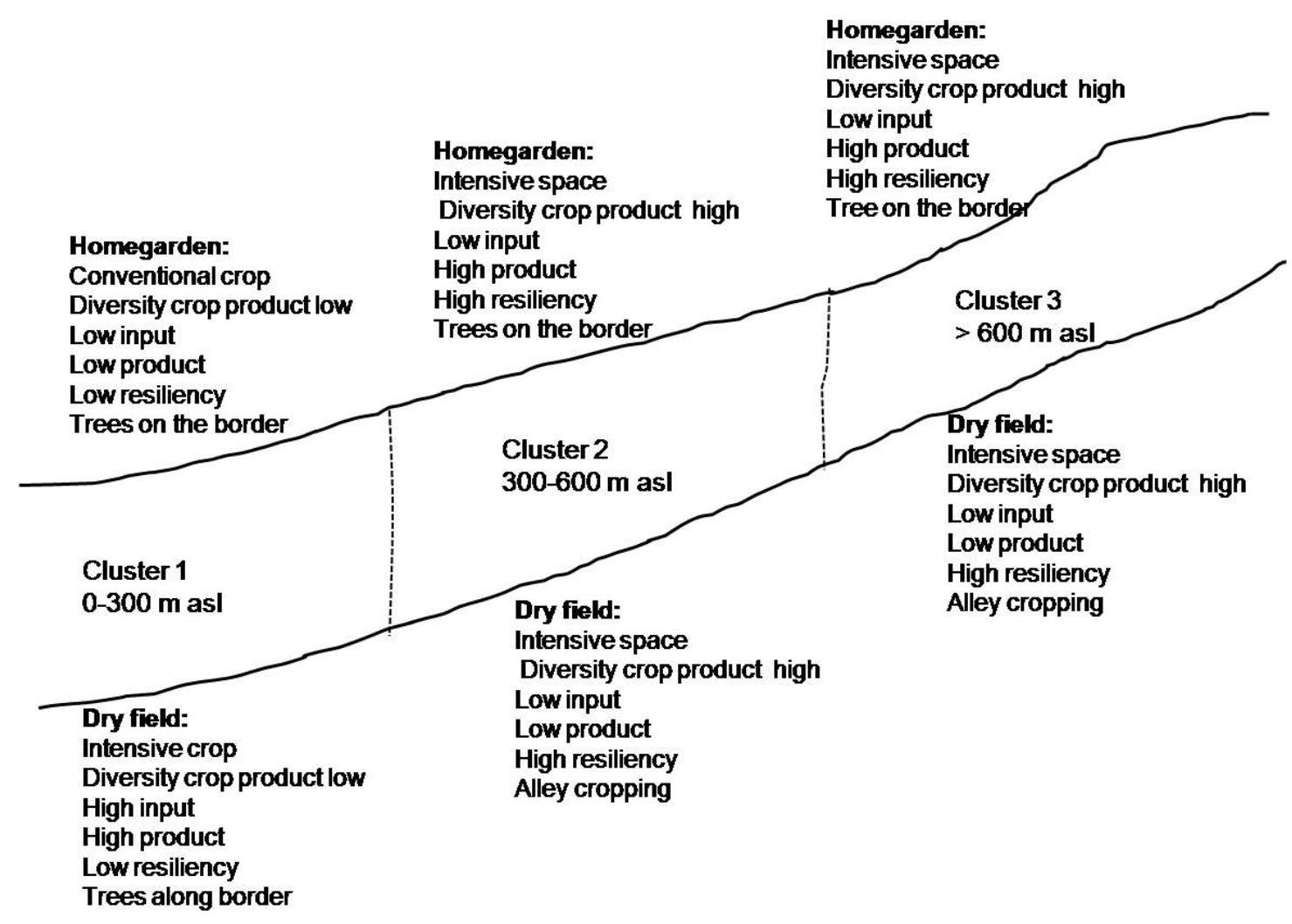

Figure 1. Homegarden-dry field typology in Kulon Progo

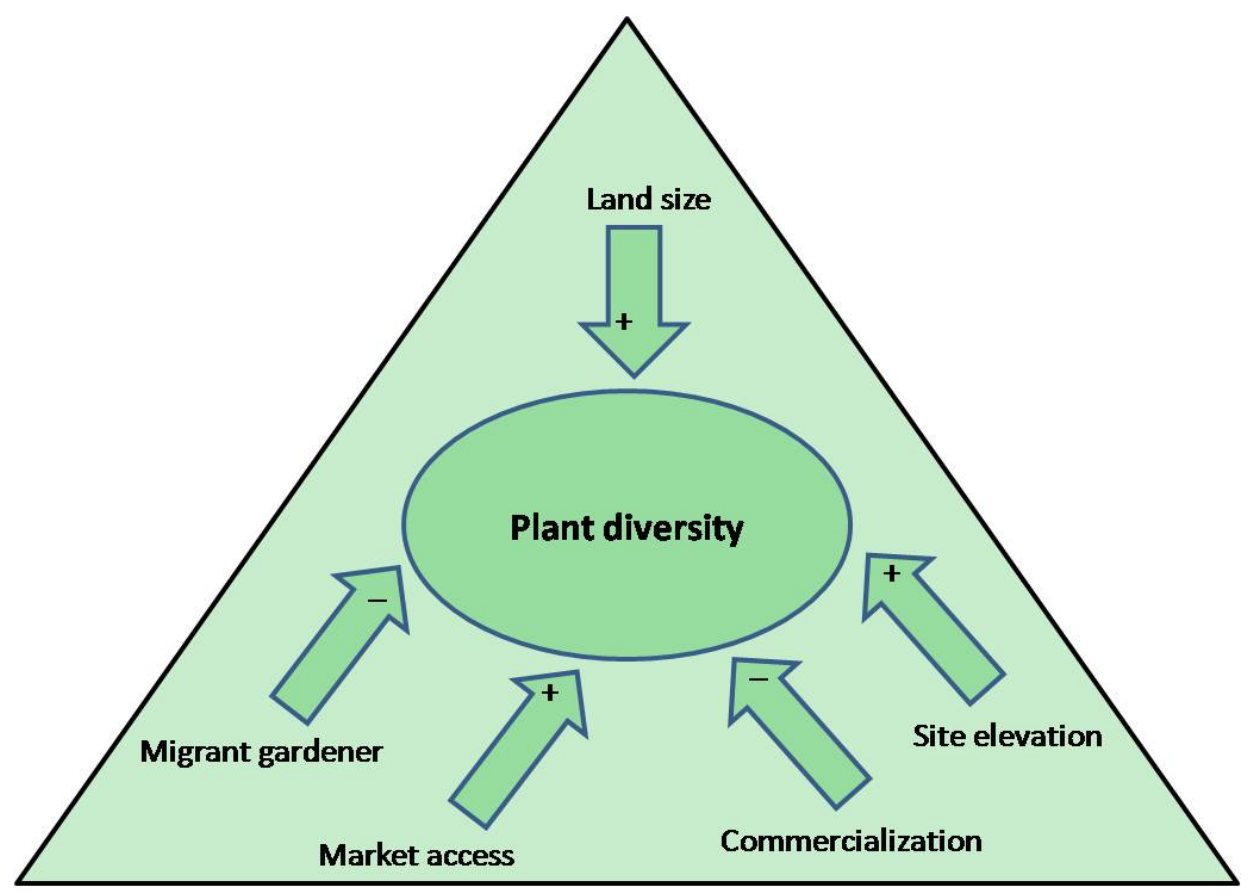

Figure 2. Species diversity determining factors 


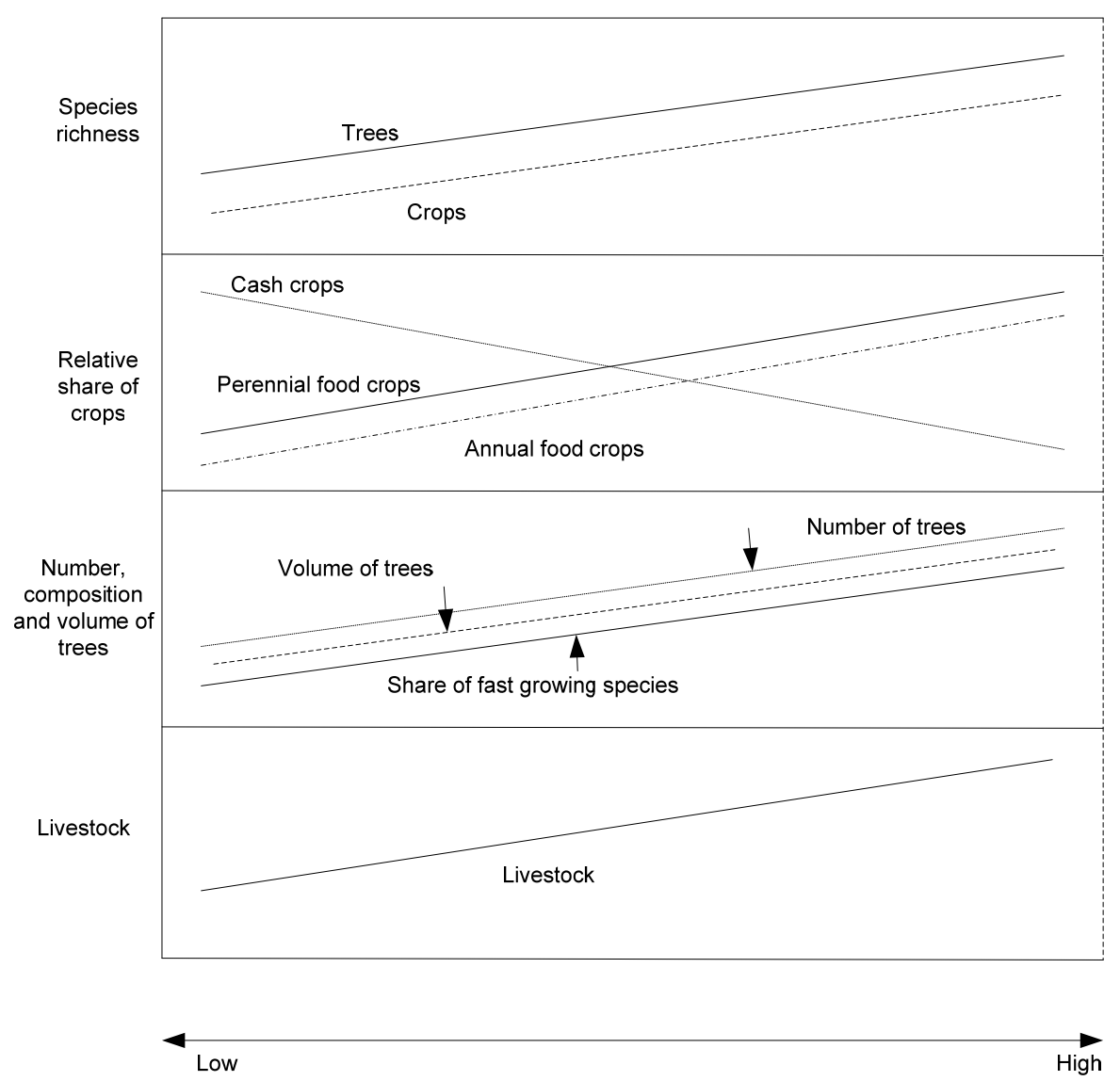

Figure 3. Agroforestry dynamics based on land width

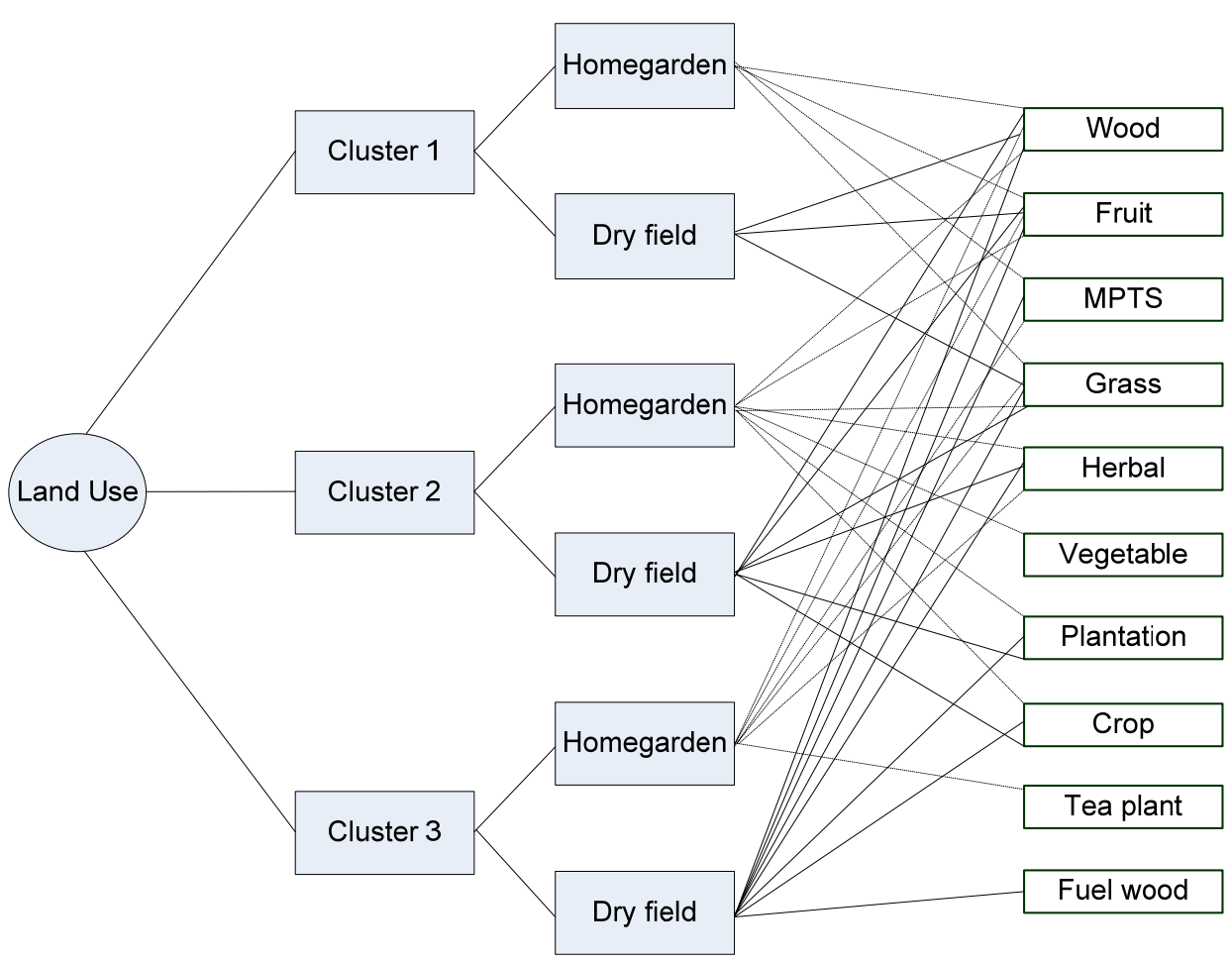

Figure 4. Agroforestry classification based on its usage 


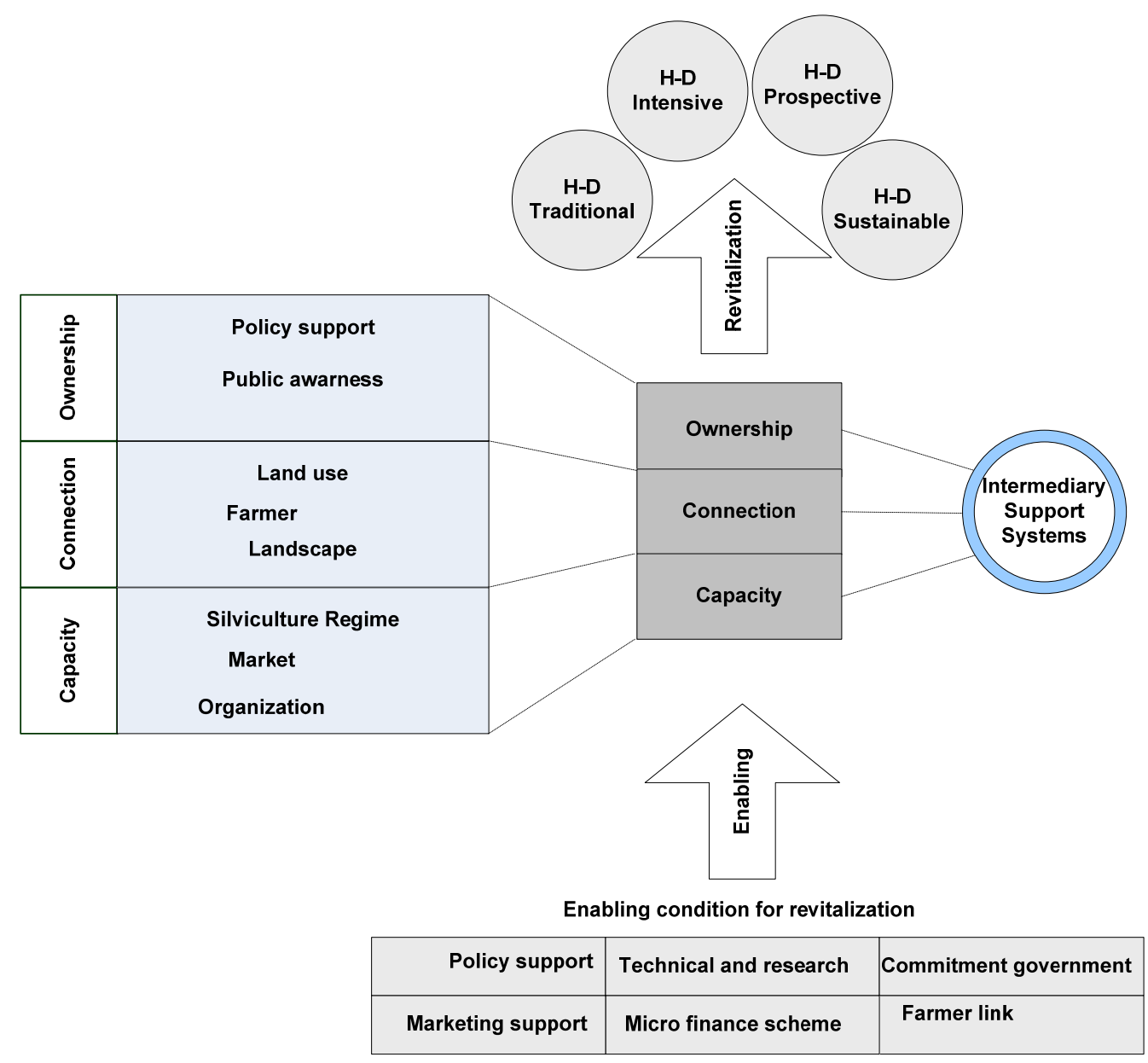

Figure 5. Homegarden and dry field revitalization scheme 